\title{
Review \\ Fibrinogen and Antifibrinolytic Proteins: Interactions and Future Therapeutics
}

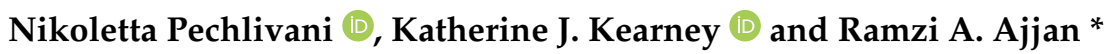 \\ Division of Cardiovascular \& Diabetes Research, Leeds Institute of Cardiovascular and Metabolic \\ Medicine (LICAMM), University of Leeds, Leeds LS2 9JT, UK; N.Pechlivani@leeds.ac.uk (N.P.); \\ K.J.Kearney@leeds.ac.uk (K.J.K.) \\ * Correspondence: R.Ajjan@leeds.ac.uk
}

Citation: Pechlivani, N.; Kearney, K.J.; Ajjan, R.A. Fibrinogen and Antifibrinolytic Proteins: Interactions and Future Therapeutics. Int. J. Mol. Sci. 2021, 22, 12537. https://doi.org/ 10.3390/ijms222212537

Academic Editor: Nobuo Okumura

Received: 28 October 2021

Accepted: 18 November 2021

Published: 21 November 2021

Publisher's Note: MDPI stays neutral with regard to jurisdictional claims in published maps and institutional affiliations.

Copyright: (c) 2021 by the authors. Licensee MDPI, Basel, Switzerland. This article is an open access article distributed under the terms and conditions of the Creative Commons Attribution (CC BY) license (https:// creativecommons.org/licenses/by/ $4.0 /)$.
Abstract: Thrombus formation remains a major cause of morbidity and mortality worldwide. Current antiplatelet and anticoagulant therapies have been effective at reducing vascular events, but at the expense of increased bleeding risk. Targeting proteins that interact with fibrinogen and which are involved in hypofibrinolysis represents a more specific approach for the development of effective and safe therapeutic agents. The antifibrinolytic proteins alpha- 2 antiplasmin $(\alpha 2 \mathrm{AP})$, thrombin activatable fibrinolysis inhibitor (TAFI), complement C3 and plasminogen activator inhibitor-2 (PAI-2), can be incorporated into the fibrin clot by FXIIIa and affect fibrinolysis by different mechanisms. Therefore, these antifibrinolytic proteins are attractive targets for the development of novel therapeutics, both for the modulation of thrombosis risk, but also for potentially improving clot instability in bleeding disorders. This review summarises the main properties of fibrinogen-bound antifibrinolytic proteins, their effect on clot lysis and association with thrombotic or bleeding conditions. The role of these proteins in therapeutic strategies targeting the fibrinolytic system for thrombotic diseases or bleeding disorders is also discussed.

Keywords: fibrinogen; antifibrinolytic proteins; therapeutics; thrombosis; bleeding

\section{Introduction}

The formation of obstructive intravascular thrombi remains a significant cause of morbidity and mortality worldwide [1]. These thrombi can form in arterial and venous vascular beds with the former having a rich presence of platelets [2,3]. This explains why it is mainly antiplatelet therapies that are chosen for the prevention of atherothrombotic disease, while anti-coagulants are used for the treatment and prevention of venous occlusion. However, the clinical management of arterial disease has undergone constant change over the past decade, as clinical outcome studies have shown that the combination of an antiplatelet and an anticoagulant is particularly effective at preventing atherothrombotic events [4,5]. The beneficial effects of combination therapies are not surprising given recent studies demonstrating that fibrin clot characteristics are predictors of clinical outcome in individuals at high risk of atherothrombosis [6-8]. Anticoagulants typically reduce fibrin network formation and can also make clots less robust, thus decreasing resistance to lysis, in turn reducing the risk of thrombotic vascular occlusion. A central difficulty in preventing vascular occlusion is the increased risk of bleeding events with more powerful anti-thrombotic agents. Therefore, there is a fine balance between inhibiting platelet function/fibrin network formation and ensuring bleeding risks are kept to a minimum. While newer antiplatelet and anticoagulant therapies are more effective at preventing thrombosis, risk of bleeding remains high. Rather than using powerful agents that have a "global effect" on platelet function and/or coagulation proteins, a more balanced strategy would be to target fibrin clot formation and breakdown, thus having agents with an improved efficacy/safety ratio. One of these potential pathways is targeting the factors responsible 
for hypofibrinolysis, given this is a known risk factor for thrombosis even with the use of powerful antiplatelet agents $[6,7]$.

Altered incorporation of antifibrinolytic proteins into the fibrin network is an important mechanism that determines fibrinolysis potential [9]. Unlike the clinical use of warfarin (which inhibits synthesis of four coagulation proteins, factors II, VII, IX, and X) [10] or novel oral anticoagulants (NOAC) that inhibit factor Ila or Xa [11], the strategy of interfering with fibrinogen-bound or cross-linked antifibrinolytic proteins will offer the opportunity for a more targeted approach to improve the hypofibrinolytic environment with the real possibility of low risk of bleeding.

In the current narrative review, we discuss the interaction between fibrinogen and fibrin-bound antifibrinolytic proteins, describing their main characteristics and effects on the fibrinolytic process in different disease states. We also explore the role of these proteins as therapeutic targets to reduce thrombosis or bleeding risk, including latest techniques in the field that modulate the function of these proteins.

\section{Interactions of Fibrinogen with Antifibrinolytic Proteins}

Fibrinogen, a soluble glycoprotein with a molecular weight of $340 \mathrm{kDa}$, consists of two sets of three polypeptide chains $(\mathrm{A} \alpha, \mathrm{B} \beta$, and $\gamma)$, encoded by three genes $F G A$, $F G B$, and FGG. Release of fibrinopeptides $\mathrm{A}$ and $\mathrm{B}$ from the $\mathrm{N}$-terminal of the $\mathrm{A} \alpha$ and $B \beta$ chains of fibrinogen by thrombin results in the conversion of fibrinogen to fibrin monomers [12,13]. The fibrin monomers polymerise to form fibrin protofibrils, which subsequently assemble to produce a fibrin network [14]. Fibrinogen plays an important role in several pathophysiological processes including thrombogenesis, inflammation, tissue injury, and atherogenesis. Therefore, it interacts with a number of proteins such as Mac-1 and alpha X beta 2 integrins on the surface of leukocytes, glycoprotein IIb-IIIa receptor on the platelet surface, fibronectin, matrix metalloproteinase-2 (MMP-2), and several growth factors including vascular endothelial growth factor (VEGF), basic fibroblast growth factor (bFGF), and insulin-like growth factor-binding protein 3 (IGFBP-3) [15-19].

This review focuses on the proteins that interact with fibrin(ogen) and are involved in the antifibrinolytic process; these are summarized in Figure 1 and Table 1.

Table 1. Summary of fibrin-bound antifibrinolytic proteins alpha-2 antiplasmin ( $\alpha 2 \mathrm{AP})$, thrombin activatable fibrinolysis inhibitor (TAFI), complement C3, and plasminogen activator inhibitor-2 (PAI-2).

\begin{tabular}{|c|c|c|c|c|}
\hline & $\alpha 2 \mathrm{AP}$ & TAFI & $\mathrm{C} 3$ & PAI-2 \\
\hline Mass (kDa) & $\sim 70$ & 56 & 187 & 47 \\
\hline Human gene & SERPINF2 & CPB2 & C3 & SERPINB2 \\
\hline Synthesis/expression & Liver, kidney, and brain & $\begin{array}{c}\text { Liver and } \\
\text { megakaryocytes }\end{array}$ & Liver and immune cells & $\begin{array}{c}\text { Monocytes, } \\
\text { macrophages, } \\
\text { keratinocytes, } \\
\text { fibroblasts, and } \\
\text { placenta }\end{array}$ \\
\hline $\begin{array}{l}\text { Circulating plasma } \\
\text { concentration }\end{array}$ & $70 \mu \mathrm{g} / \mathrm{mL}$ & $4-15 \mu \mathrm{g} / \mathrm{mL}$ & $1.2 \mathrm{mg} / \mathrm{mL}$ & Below detection limit \\
\hline $\begin{array}{l}\text { Antifibrinolytic } \\
\text { function }\end{array}$ & $\begin{array}{l}\text { Direct binding to, and } \\
\text { inhibition of, plasmin } \\
\text { and cross-linking into } \\
\text { the clot making it more } \\
\text { resistant to lysis }\end{array}$ & $\begin{array}{l}\text { Protects the clot from } \\
\text { lysis by cleaving off } \\
\text { C-terminal lysine } \\
\text { residues from fibrin, } \\
\text { which reduces } \\
\text { plasminogen and tPA } \\
\text { binding and } \\
\text { subsequent plasmin } \\
\text { generation }\end{array}$ & $\begin{array}{l}\text { Incorporation into the } \\
\text { fibrin clot causes } \\
\text { prolongation of } \\
\text { fibrinolysis }\end{array}$ & $\begin{array}{l}\text { Cross-linking into } \\
\text { fibrin at a site close to } \\
\text { tPA binding site affects } \\
\text { fibrin clot lysis }\end{array}$ \\
\hline
\end{tabular}




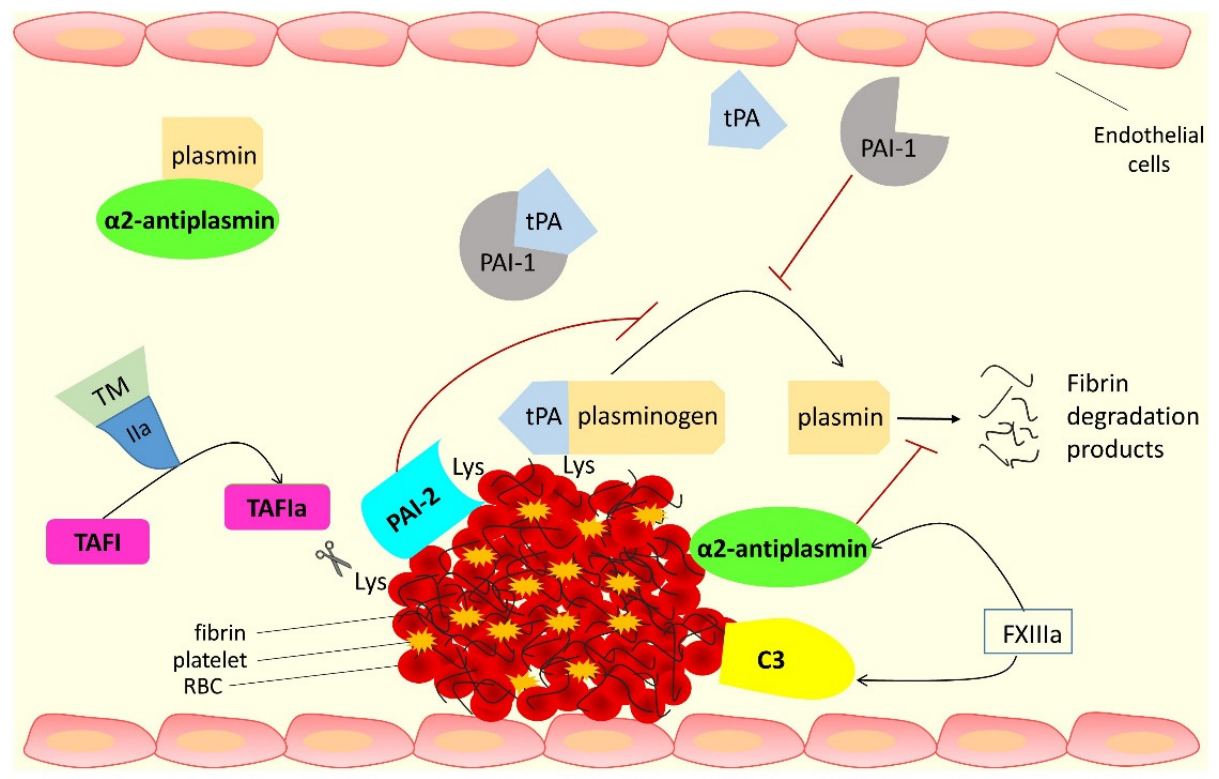

Figure 1. The role of antifibrinolytic proteins in the fibrinolytic process. The fibrin component of the thrombus is degraded by plasmin, generated by tissue plasminogen activator (tPA) activation of plasminogen. Anti-fibrinolytic protein plasminogen activator inhibitor-1 (PAI-1) binds tPA, preventing plasminogen activation. Alpha-2 antiplasmin ( $\alpha 2 \mathrm{AP})$ forms a stable complex with plasmin in the circulation or becomes cross-linked into the fibrin clot by activated FXIII (FXIIIa), which makes the clot more resistant to fibrinolysis. Thrombin activatable fibrinolysis inhibitor (TAFI) is activated by thrombin (IIa) in complex with thrombomodulin (TM). Activated TAFI (TAFIa) cleaves off lysine residues (Lys) from the fibrin surface therefore decreasing plasminogen and tPA binding, thus reducing plasmin generation. TAFI, as well as plasminogen activator inhibitor-2 (PAI-2), can also be cross-linked into the fibrin clot by FXIIIa. Complement C3 is bound and cross-linked to the fibrin clot by FXIIIa, causing prolongation of fibrinolysis.

\subsection{Alpha-2 Antiplasmin ( $\alpha 2 A P)$}

$\alpha 2 \mathrm{AP}$ is a $\sim 70 \mathrm{kDa}$ glycoprotein, a member of the serine protease inhibitor (serpin) family, and is mainly produced in the liver, but can also be synthesised by the kidney and brain [20-24]. Human $\alpha 2 \mathrm{AP}$ gene is SERPINF2, located on chromosome 17p13.3 and encodes a single-chain protein of 464 amino acid residues with a 27 amino acid residue signal peptide [22,25]. $\alpha 2 \mathrm{AP}$ is the main physiological inhibitor of plasmin and circulates in plasma at a concentration of approximately $70 \mu \mathrm{g} / \mathrm{mL}(1 \mu \mathrm{M})[26,27]$.

When $\alpha 2 \mathrm{AP}$ and plasmin form a 1:1 stable complex, either in the circulation or on the fibrin surface, plasmin is inhibited [28]. The half-life of $\alpha 2 \mathrm{AP}$ is 2.6 days, but plasmin-antiplasmin (PAP) complexes have a much shorter half-life of approximately 0.5 days [29]. During clot formation, $\alpha 2 \mathrm{AP}$ becomes covalently cross-linked into the fibrin clot by activated factor XIII (FXIIIa) making the clot more resistant to degradation by plasmin [30]. The cross-linking mainly occurs between glutamine residue at position 14 of the $\alpha 2 \mathrm{AP}$ molecule and lysine residue at position 303 of the $\alpha$ chain of fibrin [31], although additional cross-linking sites on fibrinogen have been proposed [32].

\subsubsection{Role of $\alpha 2 \mathrm{AP}$ Genetic and Post-Translational Variants}

$\alpha 2 \mathrm{AP}$ undergoes both amino terminal ( $\mathrm{N}$-terminal) and carboxyl terminal (C-terminal) proteolytic modifications to produce various $\alpha 2 \mathrm{AP}$ isoforms in the circulation. About $30 \%$ of circulating $\alpha 2 \mathrm{AP}$ is the native form with a methionine (Met) residue at the $\mathrm{N}$ terminus (Met- $\alpha 2 \mathrm{AP})$, and the other $70 \%$ is N-terminally cleaved by antiplasmin-cleaving enzyme (APCE) between proline (Pro) residue at position 12 and asparagine (Asn) residue at position 13, resulting in the $\alpha 2 \mathrm{AP}$ form with an Asn residue at the $\mathrm{N}$-terminus (Asn$\alpha 2 \mathrm{AP})$ [24]. It has been shown that Asn- $\alpha 2 \mathrm{AP}$ is cross-linked to fibrin by FXIIIa 13 times 
faster than native Met- $\alpha 2 \mathrm{AP}$, explaining studies that reported superior inhibition of fibrin clot lysis by Asn- $\alpha 2 \mathrm{AP}$ compared with Met- $\alpha 2 \mathrm{AP}$ [30,33-35]. It has also been suggested that genetic variation in the SERPINF2 gene affects $\mathrm{N}$-terminal heterogeneity of $\alpha 2 \mathrm{AP}$, as the arginine (Arg)-to-tryptophan (Trp) polymorphism at position 6 was shown to influence the rate of $\alpha 2 \mathrm{AP}$ incorporation into fibrin clots. Specifically, Met- $\alpha 2 \mathrm{AP}$ (Arg6) was cleaved about eight times more rapidly than Met- $\alpha 2 A P$ (Trp6) [36]. Recently, Bronic et al. have shown in a Croatian cohort that individuals with Arg6Trp $\alpha 2 \mathrm{AP}$ CC genotype had an almost 4-fold higher risk of coronary artery disease compared with Arg6Trp $\alpha 2 \mathrm{AP}$ TT genotype [37].

The C-terminal of $\alpha 2 \mathrm{AP}$ is also post-translationally modified, and two forms are present in plasma of which only one can bind plasminogen, referred to as plasminogen binding $\alpha 2 \mathrm{AP}$ (PB- $\alpha 2 \mathrm{AP}$ ) while the other form fails to bind plasminogen and is termed non-plasminogen binding $\alpha 2 \mathrm{AP}(\mathrm{NPB}-\alpha 2 \mathrm{AP})[38,39]$. The liver produces the PB- $\alpha 2 \mathrm{AP}$ form, and this constitutes $65 \%$ of circulating $\alpha 2 \mathrm{AP}$, while NPB- $\alpha 2 \mathrm{AP}$ is formed in the circulation $[25,40,41]$. The C-terminal of $\alpha 2 \mathrm{AP}$ plays a significant role in the interaction with plasmin(ogen), as this interaction takes place via the lysine $(\mathrm{K})$ residues positioned in the C-terminal of $\alpha 2 \mathrm{AP}\left(\mathrm{K}^{418}, \mathrm{~K}^{427}, \mathrm{~K}^{434}, \mathrm{~K}^{441}, \mathrm{~K}^{448}\right.$, and $\left.\mathrm{K}^{464}\right)$ with the lysine binding sites (LBS) in the kringle domains of plasmin(ogen) [42]. Furthermore, $\alpha 2$ AP C-terminal contains an arginine-glycine-aspartic acid (RGD) sequence, important for cell recognition and cell adhesion via integrins. Functionally, this RGD sequence may modulate platelet activation, suggesting a dual role for $\alpha 2 \mathrm{AP}$ on both the cellular and protein arms of coagulation $[43,44]$. However, this is an area that is incompletely understood, and further research is required to fully elucidate the role of the RGD region in $\alpha 2 \mathrm{AP}$ function.

\subsubsection{Effects of Congenital and Acquired Deficiency of $\alpha 2 \mathrm{AP}$}

Congenital deficiency of $\alpha 2 \mathrm{AP}$, an autosomal recessive condition, causes a rare bleeding disorder. Individuals with homozygous $\alpha 2 \mathrm{AP}$ deficiency can exhibit severe bleeding, while individuals with heterozygous deficiency usually have mild bleeding tendencies or may be asymptomatic $[45,46]$. Congenital deficiency can be either quantitative with decreased protein levels or qualitative with reduced protein function [47]. Acquired deficiency may be seen in patients with various conditions such as acute leukaemia, amyloidosis, and severe liver disease [48-51]. Reduced levels of $\alpha 2 \mathrm{AP}$ have also been reported in patients with disseminated intravascular coagulation (DIC) and those undergoing thrombolytic therapy $[46,52]$.

\subsubsection{Role of $\alpha 2 \mathrm{AP}$ in Thrombotic Disorders}

Increased levels of $\alpha 2 \mathrm{AP}$ in man have shown associations with ischaemic stroke [53], while animal work has demonstrated a link between $\alpha 2 \mathrm{AP}$ and venous thrombosis $\left(\alpha 2 \mathrm{AP}^{-/-}\right.$ mice were protected against thrombosis) $[47,54]$. Several animal studies also investigated the role of $\alpha 2 \mathrm{AP}$ in pulmonary embolism, ischaemic stroke, thrombotic thrombocytopenic purpura (TTP), and arterial thrombosis, in which $\alpha 2 \mathrm{AP}$ was shown to be involved in the formation and removal of venous thrombi in mice [55-59].

\subsection{Thrombin Activatable Fibrinolysis Inhibitor (TAFI)}

TAFI is a zinc-dependent metallocarboxypeptidase, synthesised by the liver and megakaryocytes as a propeptide consisting of 423 amino acids; when the 22 amino acid signal peptide is removed, the $56 \mathrm{kDa}$ proenzyme containing 401 amino acids is secreted into the blood circulation [60-62]. The gene encoding human TAFI, CPB2, was mapped to chromosome 13 (13q14.11) and contains 11 exons [63,64]. The concentration of TAFI in plasma varies from 4 to $15 \mu \mathrm{g} / \mathrm{mL}$ and is also stored within platelet $\alpha$-granules, at approximately $50 \mathrm{ng}$ per $10^{9}$ platelets $[65,66]$. Therefore, TAFI concentration at the site of thrombus formation is much higher than circulating levels. TAFI belongs to and shares structural characteristics with the subfamily A of metallocarboxypeptidases consisting of two domains: the N-terminal activation peptide and a catalytic domain [67]. 


\subsubsection{TAFI Activation and Role of TAFI in Fibrinolysis}

TAFI can be activated by thrombin, by plasmin, or by thrombin in complex with thrombomodulin. The latter causes the most efficient TAFI activation followed by plasmin, while thrombin is the weakest activator $[68,69]$. No physiological inhibitors of TAFI have been identified, and therefore it is speculated that this protein is regulated by other mechanisms that involve intrinsic thermal instability [70]. TAFI is cross-linked by FXIIIa into the fibrin clot via three major amino acid sites, Glutamine (Gln)2, Gln5, and Gln292, and this may also play a role in facilitating its activation, enhancing its activity and protecting the fibrin clot from plasmin degradation [71]. Activated TAFI (TAFIa) protects fibrin clots from lysis by cleaving off C-terminal lysine residues from the fibrin surface which reduces plasminogen and tPA binding, consequently limiting plasmin production [60,72-74]. Moreover, TAFIa reduces plasmin binding by removing C-terminal lysine residues from fibrin thus enhancing plasmin and $\alpha 2 \mathrm{AP}$ interactions [75]. The antifibrinolytic activity of TAFI depends on the initial proenzyme plasma concentration, the TAFIa generation rate and its half-life (the half-life of TAFIa is about $10 \mathrm{~min}$ at $37^{\circ} \mathrm{C}$, about $40-50 \mathrm{~min}$ at $30^{\circ} \mathrm{C}$ and about $120-150 \mathrm{~min}$ at $\left.22^{\circ} \mathrm{C}\right)[76,77]$.

\subsubsection{Role of TAFI Genetic and Post-Translational Variants}

Two of nineteen identified single-nucleotide polymorphisms (SNPs) located in the coding region result in amino acid substitutions, which create four TAFI isoforms of which the $325 \mathrm{Thr} /$ Ile polymorphism affects TAFIa stability and antifibrinolytic activity [61,78,79]. The $438 \mathrm{G} / \mathrm{A}$ polymorphism was reported to be a risk factor for developing venous thrombosis [80,81]. The association of TAFI single SNPs, 438 G/A, $505 \mathrm{G} / \mathrm{A}$, and $1040 \mathrm{C} / \mathrm{T}$ with protein plasma levels, and the risk of deep vein thrombosis (DVT) was investigated. Carriers of $505 \mathrm{G}$ allele showed lower plasma TAFI levels and increased DVT risk compared with 505 A carriers [82]. These contradictory results are intriguing and may be related to alterations in protein function induced by the polymorphism.

Analysis of post-translational modification of human TAFI revealed five $\mathrm{N}$-linked glycans, four of which are attached to the activation peptide and one to the catalytic domain involved in substrate binding. Upon TAFI activation, the activation peptide and attached glycans are removed, causing changes to protein properties including a shift in the isoelectric point and a reduction in solubility [83].

\subsubsection{Effects of TAFI Deficiency}

TAFI plasma levels are reduced in advanced liver disease, which may contribute to bleeding tendency observed in cirrhosis [84]. Homozygous TAFI-deficient mice develop normally, do not exhibit bleeding tendencies, and plasma clot lysis is not affected [85]. Moreover, in vivo animal work has shown that TAFI deficiency does not affect rate of arterial or venous thrombus formation, and has no effect on survival rate following experimental vascular occlusion [85]. However, another study has reported enhanced fibrinolysis in TAFI deficient mice and decreased accumulation of fibrin in the lungs in a batroxobininduced pulmonary embolism model [86]. Furthermore, TAFI deficient mice demonstrated a decrease in thrombus size in $\mathrm{FeCl}_{3}$-induced vascular injury models and enhanced fibrinolysis in a thromboembolism model $[87,88]$. More recently, it was reported that functional TAFI deficiency in haemophilia promotes maladaptive vascular remodelling in the joints after bleeding [89], suggesting a more diverse role for this protein.

\subsubsection{Role of TAFI in Thrombotic Disorders}

In the Leiden Thrombophilia Study (LETS), elevated TAFI plasma levels were associated with a small increase in the risk of venous thrombosis [90]. Furthermore, patients with high TAFI and high levels of one of the factors VIII, IX, or XI had higher relative risk for recurrence compared with patients with low levels of TAFI and one of these factors [91]. In addition to venous thrombosis, elevated TAFI levels have shown associations with ischaemic stroke [92]. In contrast, another study reported that patients with a recent 
myocardial infarction had lower TAFI levels and that high TAFI levels were associated with reduced risk of myocardial infarction [93]. As alluded to earlier, it is possible that altered protein function accounts for the association between lower levels and disease, and further mechanistic studies in this area are required.

\subsection{Complement $\mathrm{C} 3$}

Complement protein $\mathrm{C} 3$ is a main component of the human complement system and plays an important role in innate immunity. C3 is a $187 \mathrm{kDa}$ protein consisting of two chains (alpha and beta) and belongs to the $\alpha 2$-macroglobulin family [94,95]. The gene encoding human C3, called C3, is located in chromosome 19 (19p13.3) and contains 41 exons [96,97]. C3 is synthesised mainly by the liver but is also produced by immune cells and is present in plasma at high concentrations of approximately $1.2 \mathrm{mg} / \mathrm{mL}[98,99]$. Evidence suggests a link between the complement system and the coagulation/fibrinolysis cascade [100].

\subsubsection{Interaction of $\mathrm{C} 3$ with Fibrin(ogen) and Role in Fibrinolysis}

C3 has been identified as a novel clot component that is able to bind to immobilised fibrinogen and fibrin with high affinity [101,102]. C3 incorporation into fibrin clots results in prolongation of fibrinolysis in a concentration-dependent manner, while binding data from the same study indicated that there are two high-affinity binding sites for C3 on both fibrinogen and fibrin [101,102]. We have recently shown, using microarray analysis, that the $B \beta$ chain of fibrinogen contains key binding sites for C3 [103]. C3 can be both bound (non-covalently), and cross-linked to fibrin networks by FXIIIa [104,105]. Plasma levels of C3 are independently associated with a history of acute or chronic vascular injury [106-109]. Moreover, C3 has shown an association with fibrin clot lysis in 837 type 2 diabetes individuals, while increased incorporation into fibrin networks of type 1 diabetes individuals suggests this protein may become a diabetes-specific target to improve hypofibrinolysis [110,111].

\subsubsection{Role of C3 Genetic and Post-Translational Variants}

C3 genetic variants have been linked with various conditions such as severe preeclampsia, systemic lupus erythematosus (SLE), and advanced age-related macular degeneration [112-115]. However, links with vascular disease are less convincing; the Arg102Gly polymorphism has shown associations with $\mathrm{C} 3$ plasma levels, but not with the presence or severity of coronary artery disease, casting doubts on the importance of this polymorphism in vascular pathology [116].

Post-translational modifications of $\mathrm{C} 3$, and in particular glycation, may also affect its properties. Glycation of C3 may cause changes in its structure, affecting the immune properties of C3 [117]. We have recently shown that glycation of C3 enhances the antifibrinolytic activity, although the exact glycated residues are yet to be identified [103].

\subsubsection{Effects of C3 Deficiency}

Deficiencies in proteins of the complement system are usually hereditary and associated with increased susceptibility to infections [118]. Recent animal studies have revealed an association between C3 deficiency and increased angiogenesis, which may have implications for vascular occlusive disease $[119,120]$.

\subsubsection{Role of C3 in Thrombotic Disorders}

A few studies investigated the relationship between C3, SLE, and thrombosis. Early work has shown an association between C3 plasma levels and coronary artery disease [106]. Increased C3 levels have also been documented in pregnancy-related venous thrombosis [121]. However, low levels of C3 in SLE patients were associated with increased risk of thrombosis [122]. It is not only quantitative changes in the protein that are associated with thrombosis; qualitative changes can also show associations with thrombosis (such as an increase in protein phosphate content) [123]. 


\subsection{PAI-2}

Human plasminogen activator inhibitor-2 (PAI-2) is a single chain protein of 415 amino acids, primarily found as a $47 \mathrm{kDa}$ non-glycosylated intracellular form, however it is also secreted as a $60 \mathrm{kDa}$ glycosylated protein [124]. Expression of PAI-2 has been detected in monocytes, macrophages, keratinocytes, fibroblasts, and the placenta $[125,126]$. The gene encoding human PAI-2, SERPINB2, is located on chromosome 18 (18q21-23) and consists of eight exons [127]. PAI-2 is a member of the serpin superfamily and was identified as a placental tissue-derived urokinase-type plasminogen activator (uPA) inhibitor and, to a lesser extent, a tPA inhibitor [126,128-130]. Plasma concentrations of PAI-2 are normally below detection limit, however during pregnancy, elevated levels have been reported, which also applies to some serious conditions such as myelomonocytic leukaemias and severe sepsis [126,130-132].

\subsubsection{Cross-Linking to Fibrin and Inhibition of Plasmin Generation by PAI-2}

Unlike other serpins, PAI-2 has an extension of exon 3 that encodes a unique domain named C-D loop [133]. This contains glutamine residues that form a substrate for transglutaminases and FXIIIa [134]. It has been shown that Gln 83 and 86 residues are important for cross-linking PAI-2 to several Lys residues $(148,176,183,230,413$, and 457) on the fibrin $\alpha$ chain $[135,136]$. Cross-linking to $\alpha$ Lys 148 may be crucial for PAI-2 activity, given this site is close to a tPA binding site (148-160) [137]. Furthermore, cross-linking of PAI-2 and $\alpha 2 \mathrm{AP}$ to fibrin $\alpha$ chain can occur simultaneously using different lysine residues, further enhancing resistance to fibrin clot lysis [138].

\subsubsection{Role of PAI-2 Genetic and Post-Translational Variants}

Two PAI-2 variants (variant A consisting of Asn120, Asn404, and Ser413, and variant B consisting of Asp120, Lys404, and Cys413) have shown no association with myocardial infarction [139], although others documented an association [140]. Furthermore, the PAI-2 variant rs8093048 was associated with coronary artery disease in Chinese Han population (a total of 925 individuals participated in this study: 407 patients with coronary artery disease and 518 healthy controls) [141], while Ser(413)/Cys (rs6104) failed to show an association with premature coronary artery disease in a smaller study of southern Iran population (200 patients and 200 control subjects participated in this study) [142].

\subsubsection{Effects of PAI-2 Deficiency}

Deficiency of PAI-2 has not been reported in humans or other mammals, suggesting a vital role of this protein in embryogenesis. However, PAI-2 deficient mice had normal development, survival, fertility, and response to infections [143]. While no clear links with vascular disease have been documented, PAI-2 deficiency has shown an association with malignant tumour growth and metastasis by mechanisms that remain unclear [144].

\subsubsection{Role of PAI-2 in Thrombotic Disorders}

While PAI-2 has been investigated in malignant disorders, its role in vascular disease in the absence of malignancy remains unclear. An association of PAI-2 with DVT was reported in animal model of stasis, while PAI-2 deficient mice showed enhanced venous thrombus resolution [145]. This suggests a role for PAI-2 in venous thrombosis and human studies to investigate the role of this protein in clinical thrombosis are warranted.

\section{Targeting the Antifibrinolytic Proteins for Developing Therapeutics}

\subsection{Therapeutics for Thrombotic Disorders}

Antifibrinolytic proteins represent attractive targets for the development of therapeutics to modulate thrombosis risk. Various methodologies have been explored to inhibit the functions of antifibrinolytic proteins; most revolve around the production of proteinspecific monoclonal antibodies. 


\subsubsection{Targeting $\alpha 2 \mathrm{AP}$}

Monoclonal antibodies that inhibit $\alpha 2 \mathrm{AP}$ have been shown to enhance fibrinolysis [146-149]. A monoclonal antibody which inactivated $\alpha 2 \mathrm{AP}$ was shown to reduce brain infarction, swelling, and haemorrhage in a murine model of thromboembolic stroke [150]. Furthermore, an $\alpha 2 \mathrm{AP}$ inactivating antibody increased thrombus dissolution and reduced stroke mortality compared to tPA therapy in mice [59]. More recently, Singh and colleagues used a humanised $\alpha 2 \mathrm{AP}$ mouse model of pulmonary embolism to investigate the effects of pharmacological recombinant tPA (r-tPA) and $\alpha 2 \mathrm{AP}$ inhibition on fibrinolysis and bleeding [151]. $\alpha 2$ AP-inactivating monoclonal antibody alone or combined with low dose r-tPA enhanced thrombus dissolution with low bleeding risk [151]. The $\alpha 2 \mathrm{AP}$-inactivating monoclonal antibody was also demonstrated to increase fibrinolysis in a mouse model of venous thrombosis, suggesting a role for $\alpha 2 \mathrm{AP}$ inhibition in DVT [54].

Alternative approaches to antibodies have also been explored; synthetic peptides mimicking the N-terminal of $\alpha 2 \mathrm{AP}$ were used as "competitive substrates", thus reducing FXIIIa-mediated $\alpha 2 \mathrm{AP}$ incorporation into fibrin networks [152,153]. Fusion of human serum albumin (HSA) to the $\alpha 2 \mathrm{AP} \mathrm{N}$-terminal motif has also been shown to reduce fibrinolytic resistance by a similar mechanism [154]. The $\alpha 2$ AP-HSA protein could be cross-linked by FXIIIa to fibrinogen and fibrin, competing with native $\alpha 2 \mathrm{AP}$ and reducing the $\alpha 2$ AP-dependent resistance to fibrinolysis of plasma clots [154]. Furthermore, microplasmin, which is the shortened version of plasmin containing only the catalytic domain, was reported to neutralize $\alpha 2 \mathrm{AP}$ activity in healthy volunteers but the development of microplasmin as a therapeutic for cardiovascular disease has not progressed any further [155]. Moreover, given the difference in antifibrinolytic efficacy of Met- $\alpha 2 \mathrm{AP}$ and Asn- $\alpha 2 \mathrm{AP}$, APCE inhibitors were developed, which may have a role as mild enhancers of fibrinolysis [35].

\subsubsection{Targeting TAFI}

Recently, a TAFIa inhibitor, a low molecular weight compound named S62798, has been shown to enhance clot lysis in thromboelastometry experiments using whole blood and also decreased pulmonary fibrin deposition in a mouse in vivo model of thromboembolism [156]. This molecule was also investigated for its effect on bleeding using a rat tail bleeding model; administration of r-tPA was used as a positive control and TAFIa inhibitor was found to be associated with a low risk of bleeding.

Other small-molecule TAFIa inhibitors were assessed in animal studies, such as the Potato Tuber Carboxypeptidase Inhibitor (PTCI), a 39 amino acid peptide isolated from the potato tuber, reported to enhance tPA-induced arterial thrombolysis in rabbits [157]. Another TAFIa inhibitor is the product named BX 528, demonstrated to improve thrombolysis without increasing bleeding in rats, dogs, and rabbits [158]. Most recently, a low-molecular weight oral TAFIa inhibitor, DS-1040, was suggested as a potential therapeutic agent to enhance fibrinolysis with low bleeding risk [159]. Interestingly, DS-1040 has been further evaluated in a phase 1 human study in order to assess safety (including bleeding time), tolerability, pharmacokinetics and pharmacodynamics [160].

In addition to small molecule inhibitors, monoclonal antibodies against TAFI have been raised which can interfere with TAFIa activity or TAFI activation [161]. However, some of these monoclonal antibodies against human TAFI did not have cross-reactivity with mouse or rat TAFI and therefore could not be further tested in animal studies [161]. Five monoclonal antibodies against rat TAFI shown to enhance clot lysis have undergone mechanistic studies, demonstrating the ability to destabilize TAFIa, block access to the protein's active site, or prevent binding of TAFIa to the fibrin clot [162]. Data from another study of TAFI inhibition by a monoclonal antibody suggested that the antibody MATCK26D6 exerts its activity by blocking the access of TAFI activators such as plasmin and thrombin [163]. The MA-TCK26D6 inhibitory monoclonal antibody showed a profound effect in enhancing fibrinolysis in a mouse thromboembolism model. 
Nanobodies were also screened against mouse TAFI and one nanobody (VHH-mTAFIi49) was demonstrated to decrease fibrin deposition in a mouse thromboembolism model [164].

Others have investigated inhibition of two pathways, using a heterodimer diabody against TAFI and PAI-1 in mouse models of thrombosis and stroke. The bispecific antibody was able to exhibit a profibrinolytic effect with low bleeding risk [165].

\subsubsection{Targeting Complement $\mathrm{C} 3$}

C3 prolongs clot lysis, an effect that is exaggerated in individuals with diabetes, making it a potential disease-specific target. Using Affimer technology, we have recently shown that fibrinogen-binding, C3 specific Affimers can modulate clot lysis in plasma samples from healthy controls and individuals with diabetes [166]. These results suggest that $\mathrm{C} 3$ represents a promising therapeutic target for the reduction in thrombotic risk and future in vivo animal studies are warranted.

As coronavirus disease (COVID-19) is continuing to spread around the world, C3 inhibition by a C3-targeted drug candidate, AMY-101, was recently evaluated in small independent cohorts of severe COVID-19 patients, given that targeting complement represents one approach for improving COVID-19-mediated immunothrombosis [167,168]. AMY-101 is a third-generation Cp40-based compstatin analogue able to inhibit $\mathrm{C} 3$ activation by $\mathrm{C} 3$ convertases that is currently in Phase II/III development [169].

Furthermore, research in C3 inhibition by pegcetacoplan (APL-2), a PEGylated C3 inhibitor, is ongoing in patients with paroxysmal nocturnal haemoglobinuria $(\mathrm{PNH})$, a rare acquired life-threatening hematologic disease that causes complications through both haemolysis and thrombosis $[170,171]$.

\subsubsection{Targeting PAI-2}

Although PAI-2 deficiency has been associated with increased venous thrombus resolution as discussed above, there seems to be low interest in using PAI-2 for the development of new therapeutics. This may be due to the limited and sometimes contradictory evidence linking PAI-2 to increased thrombosis risk.

\subsection{Therapeutics for Bleeding Disorders}

Treatment for bleeding disorders such as haemophilia has primarily focused on replacing the missing coagulation factor. Although recombinant bioengineering has improved various aspects of replacement therapies (i.e., decreased immunogenicity, increased efficacy, and extended half-lives), novel molecules are in development to further improve management of haemophilia [172].

One approach is the use of adjunctive antifibrinolytic therapies to reduce bleeding complications in haemophilia. The addition of TAFI helped to reduce clot lysis in haemophilic plasma and stabilised the fibrin network [173]. This strategy was also effective when TAFI (or thrombomodulin) was added to the plasma of haemophilia patients with FVIII inhibitory antibodies [173]. Another study showed that soluble thrombomodulin (Solulin) improved clot stability in severe haemophilia A by promoting TAFI activation [174]. In particular, the use of low Solulin concentrations prolonged clot lysis by a TAFIa-dependent mechanism [174].

The synthetic lysine analogues tranexamic acid (TXA) and epsilon aminocaproic acid (EACA) interfere with fibrin-plasmin(ogen) interaction, therefore preventing clot lysis, and are widely used clinically as antifibrinolytic agents [13]. Fibrin sealants, consisting of a mix of proteins including fibrinogen, thrombin, FXIII, and antifibrinolytic agents, are also used in surgical procedures, however a number of limitations have been reported to be associated with their application, including increased risk of thrombosis [13]. Engineered haemostatic polymer (PolySTAT) composed of various fibrin-specific binding domains has been shown to enhance clot formation and increase resistance to lysis [175]. Our group has recently demonstrated the potential use of a fibrinogen-binding Affimer protein that provides a novel methodology for stabilizing the fibrin clot and reducing bleeding 
risk [176]. The fibrinogen-specific Affimer prolonged fibrinolysis across plasma samples from healthy subjects and plasma deficient in FVIII (haemophilia A). Importantly, the addition of Affimer normalised the short lysis time in this condition, indicating that the Affimer has the capability to work in pathological conditions [176]. Given that Affimers can also facilitate fibrinolysis, as discussed above, the Affimer technology has the potential to be used both for thrombotic and bleeding conditions and animal in vivo studies with these molecules are warranted.

Future therapeutic strategies for the treatment of bleeding disorders such as haemophilia $\mathrm{A}$ and $\mathrm{B}$ are likely to focus on extended half-life coagulation factors, although adjunctive therapies targeting the antifibrinolytic proteins have the potential to improve efficacy of the replaced clotting factors and this remains an area for future research.

A schematic representation of the therapeutic approaches involving antifibrinolytic proteins targeting hypofibrinolysis or clot instability for thrombotic or bleeding disorders, respectively, is shown in Figure 2.

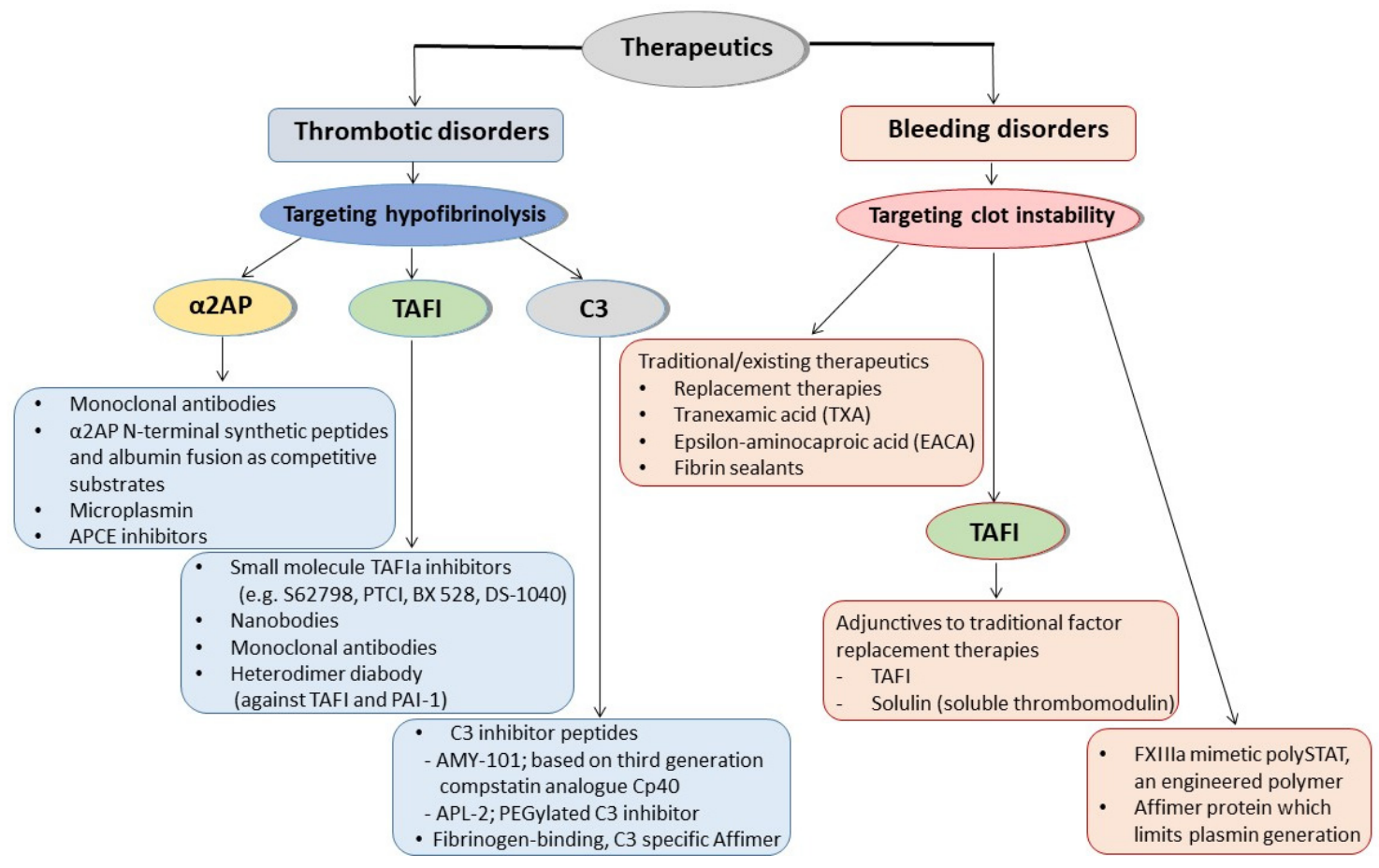

Figure 2. Antifibrinolytic proteins as therapeutic targets for thrombotic or bleeding disorders. Alpha-2 antiplasmin ( $\alpha 2 \mathrm{AP})$, thrombin activatable fibrinolysis inhibitor (TAFI) and complement protein C3 are proteins with antifibrinolytic activity that are promising therapeutic targets in thrombotic disorders. Monoclonal antibodies that inhibit $\alpha 2 \mathrm{AP}$, synthetic peptides, or albumin fusion proteins that mimic the N-terminus of $\alpha 2 \mathrm{AP}$ and act as 'competitive substrates', microplasmin, and antiplasmin-cleaving enzyme (APCE) inhibitors that enhance fibrinolysis have been developed and studied as potential therapeutics to reduce thrombosis. Small molecule TAFIa inhibitors, nanobodies, and monoclonal antibodies against TAFI, as well as heterodimer diabody against TAFI and PAI-1 have also been investigated. Complement C3 inhibitor peptides have been tested as drug candidates for thrombotic diseases, and Affimer technology was employed to develop fibrinogenbinding C3 specific Affimers that modulate clot lysis. On the other hand, antifibrinolytic proteins and processes contributing to clot stability are targeted in bleeding disorders. Traditionally used therapeutics for bleeding disorders mainly focus on replacement of the missing coagulation factor(s). Antifibrinolytic lysine analogues tranexamic acid (TXA) and epsilonaminocaproic acid (EACA) are also used to limit bleeding. Fibrin sealants are used during surgical procedures to aid the maintenance of haemostasis. TAFI has been investigated as an adjunctive therapy for individuals with bleeding disorders, as has Solulin, a recombinant soluble analogue of human thrombomodulin. More recently, PolySTAT, an engineered protein scaffold that binds fibrin and acts similarly to FXIIIa, was able to strengthen clots and reduce bleeding in animal models. Fibrinogen-specific Affimers have also been developed and shown recently to represent a novel methodology for reducing bleeding. 


\section{Conclusions and the Future}

While a large number of studies have investigated the role of fibrin-incorporated antifibrinolytic proteins in health and disease, characterization of their exact role in vascular occlusive disease is incompletely understood. This is likely related to the heterogeneity of the population studied, small numbers analysed, and/or the sensitivity of the methodologies applied. While more research in this area is needed, some of these antifibrinolytic proteins are emerging as potential therapeutic targets given their role in disease states and consistent effect on fibrinolysis. Perhaps the antifibrinolytic protein with the most evidence for use as a therapeutic target is $\alpha 2 \mathrm{AP}$; indeed, several approaches have been explored to modulate protein activity. Monoclonal antibodies against $\alpha 2 \mathrm{AP}$ have been particularly effective at altering $\alpha 2 \mathrm{AP}$ activity, and these have even been tested in phase I and phase II clinical studies, but none have made it into routine clinical practice to date. TAFI inhibitors have also been developed, with some showing early promising results, while there has been little investment in developing PAI-2 inhibitors given their inconsistent role in disease.

Interestingly, the use of antifibrinolytic proteins as therapeutic targets is not limited to thrombotic conditions, but also bleeding disorders, where they may prove to be effective as adjunctive therapies or even as main agents to stop blood loss.

Taken together, the molecular mechanisms involved in function of fibrin-incorporated antifibrinolytic proteins are largely understood, but more work is needed to fully elucidate the groups, or subgroups, of individuals who would benefit the most from antifibrinolyticbased therapies. While a number of approaches for modulating the function of antifibrinolytic proteins have been developed, more work is required to ensure that such therapies are effective in vivo (i.e., good efficacy/safety profile) and do not have unwanted "off target" effects. Overall, current evidence suggests that antifibrinolytic-directed therapies have the potential to be novel antithrombotic agents with a low risk of bleeding, while also being relevant to the discovery of agents that can be used in bleeding disorders. Appropriate collaborations between scientists, clinicians, and the pharmaceutical industry should help to make antifibrinolytic-directed therapies part of daily clinical practice.

Author Contributions: N.P. designed the review, undertook the literature search, wrote the manuscript, and prepared the original figures. R.A.A. designed the review, wrote the manuscript, and critically reviewed the manuscript. K.J.K. critically reviewed and edited the manuscript. All authors have read and agreed to the published version of the manuscript.

Funding: This research received no external funding.

Conflicts of Interest: The authors declare no conflict of interest. Work of RA Ajjan group is kindly funded by grants from Diabetes UK, BHF, BBSRC, NIHR and Abbott Diabetes Care.

\section{References}

1. Roth, G.A.; Johnson, C.; Abajobir, A.; Abd-Allah, F.; Abera, S.F.; Abyu, G.; Ahmed, M.; Aksut, B.; Alam, T.; Alam, K.; et al. Global, Regional, and National Burden of Cardiovascular Diseases for 10 Causes, 1990 to 2015. J. Am. Coll. Cardiol. 2017, $70,1-25$. [CrossRef]

2. Koupenova, M.; Kehrel, B.E.; Corkrey, H.A.; Freedman, J.E. Thrombosis and platelets: An update. Eur. Heart J. $2017,38,785-791$. [CrossRef] [PubMed]

3. Alkarithi, G.; Duval, C.; Shi, Y.; Macrae, F.L.; Ariëns, R.A. Thrombus Structural Composition in Cardiovascular Disease. Arterioscler. Thromb. Vasc. Biol. 2021, 41, 2370-2383. [CrossRef]

4. Eikelboom, J.W.; Connolly, S.J.; Bosch, J.; Dagenais, G.R.; Hart, R.G.; Shestakovska, O.; Diaz, R.; Alings, M.; Lonn, E.M.; Anand, S.S.; et al. Rivaroxaban with or without Aspirin in Stable Cardiovascular Disease. N. Engl. J. Med. 2017, 377, 1319-1330. [CrossRef] [PubMed]

5. Steffel, J.; Eikelboom, J.W.; Anand, S.S.; Shestakovska, O.; Yusuf, S.; Fo, K.A.A. The COMPASS Trial: Net Clinical Benefit of Low-Dose Rivaroxaban Plus Aspirin as Compared With Aspirin in Patients With Chronic Vascular Disease. Circulation 2020, 142, 40-48. [CrossRef] [PubMed]

6. Sumaya, W.; Wallentin, L.; James, S.K.; Siegbahn, A.; Gabrysch, K.; Himmelmann, A.; Ajjan, R.A.; Storey, R.F. Impaired Fibrinolysis Predicts Adverse Outcome in Acute Coronary Syndrome Patients with Diabetes: A PLATO Sub-Study. Thromb. Haemost. 2020, 120, 412-422. [CrossRef] [PubMed] 
7. Sumaya, W.; Wallentin, L.; James, S.K.; Siegbahn, A.; Gabrysch, K.; Bertilsson, M.; Himmelmann, A.; Ajjan, R.A.; Storey, R.F. Fibrin clot properties independently predict adverse clinical outcome following acute coronary syndrome: A PLATO substudy. Eur. Heart J. 2018, 39, 1078-1085. [CrossRef]

8. Kietsiriroje, N.; Ariens, R.A.S.; Ajjan, R.A. Fibrinolysis in Acute and Chronic Cardiovascular Disease. Semin. Thromb. Hemost. 2021, 47, 490-505. [CrossRef]

9. Kearney, K.; Tomlinson, D.; Smith, K.; Ajjan, R. Hypofibrinolysis in diabetes: A therapeutic target for the reduction of cardiovascular risk. Cardiovasc. Diabetol. 2017, 16,34. [CrossRef]

10. Kuruvilla, M.; Gurk-Turner, C. A review of warfarin dosing and monitoring. Bayl. Univ. Med Cent. Proc. 2001, 14, 305-306. [CrossRef]

11. Mekaj, A.; Mekaj, Y.; Duci, S.; Miftari, E. New oral anticoagulants: Their advantages and disadvantages compared with vitamin K antagonists in the prevention and treatment of patients with thromboembolic events. Ther. Clin. Risk Manag. 2015, 11, 967-977. [CrossRef] [PubMed]

12. Chapin, J.C.; Hajjar, K.A. Fibrinolysis and the control of blood coagulation. Blood Rev. 2015, 29, 17-24. [CrossRef]

13. Gaule, T.G.; Ajjan, R.A. Fibrin(ogen) as a Therapeutic Target: Opportunities and Challenges. Int. J. Mol. Sci. 2021, $22,6916$. [CrossRef] [PubMed]

14. Kattula, S.; Byrnes, J.R.; Wolberg, A.S. Fibrinogen and Fibrin in Hemostasis and Thrombosis. Arterioscler. Thromb. Vasc. Biol. 2017, 37, e13-e21. [CrossRef] [PubMed]

15. Sahni, A.; Francis, C.W. Vascular endothelial growth factor binds to fibrinogen and fibrin and stimulates endothelial cell proliferation. Blood 2000, 96, 3772-3778. [CrossRef] [PubMed]

16. Kamath, S.; Lip, G.Y. Fibrinogen: Biochemistry, epidemiology and determinants. QJM 2003, 96, 711-729. [CrossRef]

17. Sahni, A.; Odrljin, T.; Francis, C.W. Binding of basic fibroblast growth factor to fibrinogen and fibrin. J. Biol. Chem. 1998, 273, 7554-7559. [CrossRef]

18. Campbell, P.G.; Durham, S.K.; Hayes, J.D.; Suwanichkul, A.; Powell, D.R. Insulin-like growth factor-binding protein-3 binds fibrinogen and fibrin. J. Biol. Chem. 1999, 274, 30215-30221. [CrossRef]

19. Sarker, H.; Hardy, E.; Haimour, A.; Maksymowych, W.P.; Botto, L.D.; Fernandez-Patron, C. Identification of fibrinogen as a natural inhibitor of MMP-2. Sci. Rep. 2019, 9, 4340. [CrossRef]

20. Kawashita, E.; Kanno, Y.; Asayama, H.; Okada, K.; Ueshima, S.; Matsuo, O.; Matsuno, H. Involvement of $\alpha$-antiplasmin in dendritic growth of hippocampal neurons. J. Neurochem. 2013, 126, 58-69. [CrossRef]

21. Menoud, P.A.; Sappino, N.; Boudal-Khoshbeen, M.; Vassalli, J.D.; Sappino, A.P. The kidney is a major site of alpha(2)-antiplasmin production. J. Clin. Investig. 1996, 97, 2478-2484. [CrossRef]

22. Collen, D. Identification and some properties of a new fast-reacting plasmin inhibitor in human plasma. Eur. J. Biochem. 1976, 69, 209-216. [CrossRef] [PubMed]

23. Mullertz, S.; Clemmensen, I. The primary inhibitor of plasmin in human plasma. Biochem. J. 1976, 159, 545-553. [CrossRef] [PubMed]

24. Bangert, K.; Johnsen, A.H.; Christensen, U.; Thorsen, S. Different N-terminal forms of alpha 2-plasmin inhibitor in human plasma. Biochem. J. 1993, 291 Pt 2, 623-625. [CrossRef] [PubMed]

25. Abdul, S.; Leebeek, F.W.G.; Rijken, D.C.; De Willige, S.U. Natural heterogeneity of $\alpha 2$-antiplasmin: Functional and clinical consequences. Blood 2016, 127, 538-545. [CrossRef]

26. Wiman, B.; Collen, D. Purification and characterization of human antiplasmin, the fast-acting plasmin inhibitor in plasma. Eur. J. Biochem. 1977, 78, 19-26. [CrossRef] [PubMed]

27. Moroi, M.; Aoki, N. Isolation and characterization of alpha2-plasmin inhibitor from human plasma. A novel proteinase inhibitor which inhibits activator-induced clot lysis. J. Biol. Chem. 1976, 251, 5956-5965.

28. Wiman, B.; Collen, D. On the mechanism of the reaction between human alpha 2-antiplasmin and plasmin. J. Biol. Chem. 1979, 254, 9291-9297. [CrossRef]

29. Collen, D.; Wiman, B. Turnover of antiplasmin, the fast-acting plasmin inhibitor of plasma. Blood 1979, 53, 313-324. [CrossRef]

30. Sakata, Y.; Aoki, N. Significance of cross-linking of alpha 2-plasmin inhibitor to fibrin in inhibition of fibrinolysis and in hemostasis. J. Clin. Investig. 1982, 69, 536-542. [CrossRef]

31. Kimura, S.; Aoki, N. Cross-linking site in fibrinogen for alpha 2-plasmin inhibitor. J. Biol. Chem. 1986, 261, 15591-15595. [CrossRef]

32. Duval, C.; Ariens, R.A.S. Fibrinogen splice variation and cross-linking: Effects on fibrin structure/function and role of fibrinogen $\gamma^{\prime}$ as thrombomobulin II. Matrix Biol. 2017, 60-61, 8-15. [CrossRef] [PubMed]

33. Lee, K.N.; Jackson, K.W.; Christiansen, V.J.; Chung, K.H.; McKee, P.A. A novel plasma proteinase potentiates alpha2-antiplasmin inhibition of fibrin digestion. Blood 2004, 103, 3783-3788. [CrossRef]

34. Lee, K.N.; Jackson, K.W.; Christiansen, V.J.; Lee, C.S.; Chun, J.G.; McKee, P.A. Why alpha-antiplasmin must be converted to a derivative form for optimal function. J. Thromb. Haemost. 2007, 5, 2095-2104. [CrossRef]

35. Lee, K.N.; Jackson, K.W.; Christiansen, V.J.; Dolence, E.K.; McKee, P.A. Enhancement of fibrinolysis by inhibiting enzymatic cleavage of precursor alpha2-antiplasmin. J. Thromb. Haemost. 2011, 9, 987-996. [CrossRef] [PubMed]

36. Christiansen, V.J.; Jackson, K.W.; Lee, K.N.; McKee, P.A. The effect of a single nucleotide polymorphism on human alpha 2-antiplasmin activity. Blood 2007, 109, 5286-5292. [CrossRef] 
37. Bronić, A.; Ferenčak, G.; Bernat, R.; Krleza, J.L.; Dumić, J.; Dabelić, S. Association of fibrinogen and plasmin inhibitor, but not coagulation factor XIII gene polymorphisms with coronary artery disease. J. Med. Biochem. 2021, 40, 138-149. [CrossRef]

38. Wiman, B.; Lijnen, H.R.; Collen, D. On the specific interaction between the lysine-binding sites in plasmin and complementary sites in alpha2-antiplasmin and in fibrinogen. Biochim. Biophys. Acta BBA Protein Struct. 1979, 579, 142-154. [CrossRef]

39. Wiman, B. Affinity-chromatographic purification of human alpha 2-antiplasmin. Biochem. J. 1980, 191, 229-232. [CrossRef]

40. Wiman, B.; Nilsson, T.; Cedergren, B. Studies on a form of alpha 2-antiplasmin in plasma which does not interact with the lysine-binding sites in plasminogen. Thromb. Res. 1982, 28, 193-199. [CrossRef]

41. Kluft, C.; Los, P.; Jie, A.F.; van Hinsbergh, V.W.; Vellenga, E.; Jespersen, J.; Henny, C.P. The mutual relationship between the two molecular forms of the major fibrinolysis inhibitor alpha-2-antiplasmin in blood. Blood 1986, 67, 616-622. [CrossRef] [PubMed]

42. Lu, B.G.; Sofian, T.; Law, R.; Coughlin, P.B.; Horvath, A. Contribution of conserved lysine residues in the alpha2-antiplasmin C terminus to plasmin binding and inhibition. J. Biol. Chem. 2011, 286, 24544-24552. [CrossRef] [PubMed]

43. Takada, Y.; Ye, X.; Simon, S. The integrins. Genome Biol. 2007, 8, 215. [CrossRef]

44. Udvardy, M.; Schwartzott, D.; Jackson, K.; McKee, P.A. Hybrid peptide containing RGDF (Arg-Gly-Asp-Phe) coupled with the carboxy terminal part of alpha 2-antiplasmin capable of inhibiting platelet aggregation and promoting fibrinolysis. Blood Coagul. Fibrinolysis 1995, 6, 11-16. [CrossRef] [PubMed]

45. Miles, L.A.; Plow, E.F.; Donnelly, K.J.; Hougie, C.; Griffin, J.H. A bleeding disorder due to deficiency of alpha 2-antiplasmin. Blood 1982, 59, 1246-1251. [CrossRef] [PubMed]

46. Carpenter, S.L.; Mathew, P. Alpha2-antiplasmin and its deficiency: Fibrinolysis out of balance. Haemophilia 2008, 14, 1250-1254. [CrossRef]

47. Singh, S.; Saleem, S.; Reed, G.L. Alpha2-Antiplasmin: The Devil You Don't Know in Cerebrovascular and Cardiovascular Disease. Front. Cardiovasc. Med. 2020, 7, 608899. [CrossRef]

48. Favier, R.; Aoki, N.; de Moerloose, P. Congenital alpha(2)-plasmin inhibitor deficiencies: A review. Br. J. Haematol. 2001, 114, 4-10. [CrossRef]

49. Aoki, N.; Yamanaka, T. The alpha2-plasmin inhibitor levels in liver diseases. Clin. Chim. Acta 1978, 84, 99-105.

50. Avvisati, G.; Cate, J.W.T.; Sturk, A.; Lamping, R.; Petti, M.C.; Mandelli, F. Acquired alpha-2-antiplasmin deficiency in acute promyelocytic leukaemia. Br. J. Haematol. 1988, 70, 43-48. [CrossRef]

51. Avvisati, G.; Cate, J.W.T.; Sturk, A.; Lamping, R.; Petti, M.C.; Mandelli, F. Effective therapy with tranexamic acid in a case of chronic disseminated intravascular coagulation with acquired alpha2-antiplasmin deficiency associated with AL amyloidosis. Thromb. Haemost. 2009, 102, 1285-1287.

52. Leebeek, F.W.; Kluft, C.; Knot, E.A.; Los, P.; Cohen, A.F.; Six, A.J. Plasmin inhibitors in the prevention of systemic effects during thrombolytic therapy: Specific role of the plasminogen-binding form of alpha 2-antiplasmin. J. Am. Coll. Cardiol. 1990, 15, 1212-1220. [CrossRef]

53. Suri, M.F.K.; Yamagishi, K.; Aleksic, N.; Hannan, P.J.; Folsom, A.R. Novel hemostatic factor levels and risk of ischemic stroke: The Atherosclerosis Risk in Communities (ARIC) Study. Cerebrovasc. Dis. 2010, 29, 497-502. [CrossRef]

54. Singh, S.; Houng, A.K.; Reed, G.L. Venous stasis-induced fibrinolysis prevents thrombosis in mice: Role of $\alpha 2$-antiplasmin. Blood 2019, 134, 970-978. [CrossRef] [PubMed]

55. Butte, A.N.; Houng, A.K.; Jang, I.K.; Reed, G.L. Alpha 2-antiplasmin causes thrombi to resist fibrinolysis induced by tissue plasminogen activator in experimental pulmonary embolism. Circulation 1997, 95, 1886-1891. [CrossRef] [PubMed]

56. Matsuno, H.; Okada, K.; Ueshima, S.; Matsuo, O.; Kozawa, O. Alpha2-antiplasmin plays a significant role in acute pulmonary embolism. J. Thromb. Haemost. 2003, 1, 1734-1739. [CrossRef] [PubMed]

57. Kozawa, O.; Okada, K.; Ueshima, S.; Matsuo, O.; Uematsu, T.; Matsuno, H. Plasmin generation plays different roles in the formation and removal of arterial and venous thrombus in mice. Thromb. Haemost. 2002, 87, 98-104. [CrossRef]

58. Tersteeg, C.; Joly, B.S.; Gils, A.; Lijnen, R.; Deckmyn, H.; Declerck, P.J.; Plaimauer, B.; Coppo, P.; Veyradier, A.; Maas, C.; et al. Amplified endogenous plasmin activity resolves acute thrombotic thrombocytopenic purpura in mice. J. Thromb. Haemost. 2017, 15, 2432-2442. [CrossRef]

59. Reed, G.L.; Houng, A.K.; Wang, D. Microvascular thrombosis, fibrinolysis, ischemic injury, and death after cerebral thromboembolism are affected by levels of circulating $\alpha 2$-antiplasmin. Arterioscler. Thromb. Vasc. Biol. 2014, 34, 2586-2593. [CrossRef]

60. Foley, J.; Kim, P.Y.; Mutch, N.; Gils, A. Insights into thrombin activatable fibrinolysis inhibitor function and regulation. J. Thromb. Haemost. 2013, 11 (Suppl. 1), 306-315. [CrossRef]

61. Sillen, M.; Declerck, P.J. Thrombin Activatable Fibrinolysis Inhibitor (TAFI): An Updated Narrative Review. Int. J. Mol. Sci. 2021, 22, 3670. [CrossRef]

62. Eaton, D.; Malloy, B.; Tsai, S.; Henzel, W.; Drayna, D. Isolation, molecular cloning, and partial characterization of a novel carboxypeptidase B from human plasma. J. Biol. Chem. 1991, 266, 21833-21838. [CrossRef]

63. Vanhoof, G.; Wauters, J.; Schatteman, K.; Hendriks, D.; Goossens, F.; Bossuyt, P.; Scharpe, S. The gene for human carboxypeptidase $\mathrm{U}$ (CPU)—A proposed novel regulator of plasminogen activation-Maps to 13q14.11. Genomics 1996, 38, 454-455. [CrossRef] [PubMed]

64. Tsai, S.P.; Drayna, D. The gene encoding human plasma carboxypeptidase B (CPB2) resides on chromosome 13. Genomics 1992, 14, 549-550. [CrossRef] 
65. Bajzar, L.; Manuel, R.; Nesheim, M.E. Purification and characterization of TAFI, a thrombin-activable fibrinolysis inhibitor. J. Biol. Chem. 1995, 270, 14477-14484. [CrossRef]

66. Mosnier, L.O.; von dem Borne, P.A.; Meijers, J.C.; Bouma, B.N. Plasma TAFI levels influence the clot lysis time in healthy individuals in the presence of an intact intrinsic pathway of coagulation. Thromb. Haemost. 1998, 80, 829-835.

67. Marx, P.F.; Brondijk, T.H.C.; Plug, T.; Romijn, R.A.; Hemrika, W.; Meijers, J.C.M.; Huizinga, E.G. Crystal structures of TAFI elucidate the inactivation mechanism of activated TAFI: A novel mechanism for enzyme autoregulation. Blood 2008, 112, 2803-2809. [CrossRef] [PubMed]

68. Mao, S.-S.; Cooper, C.M.; Wood, T.; Shafer, J.A.; Gardell, S.J. Characterization of plasmin-mediated activation of plasma procarboxypeptidase B. Modulation by glycosaminoglycans. J. Biol. Chem. 1999, 274, 35046-35052. [CrossRef]

69. Bajzar, L.; Morser, J.; Nesheim, M. TAFI, or plasma procarboxypeptidase B, couples the coagulation and fibrinolytic cascades through the thrombin-thrombomodulin complex. J. Biol. Chem. 1996, 271, 16603-16608. [CrossRef]

70. Bajzar, L. Thrombin activatable fibrinolysis inhibitor and an antifibrinolytic pathway. Arterioscler. Thromb. Vasc. Biol. 2000, 20, 2511-2518. [CrossRef]

71. Valnickova, Z.; Enghild, J.J. Human procarboxypeptidase U, or thrombin-activable fibrinolysis inhibitor, is a substrate for transglutaminases. Evidence for transglutaminase-catalyzed cross-linking to fibrin. J. Biol. Chem. 1998, 273, 27220-27224. [CrossRef] [PubMed]

72. Bouma, B.N.; Mosnier, L.O. Thrombin activatable fibrinolysis inhibitor (TAFI)—How does thrombin regulate fibrinolysis? Ann. Med. 2006, 38, 378-388. [CrossRef]

73. Sakharov, D.V.; Plow, E.F.; Rijken, D.C. On the mechanism of the antifibrinolytic activity of plasma carboxypeptidase B. J. Biol. Chem. 1997, 272, 14477-14482. [CrossRef]

74. Longstaff, C.; Kolev, K. Basic mechanisms and regulation of fibrinolysis. J. Thromb. Haemost. 2015, 13 (Suppl. S1), S98-S105. [CrossRef]

75. Schneider, M.; Nesheim, M. A study of the protection of plasmin from antiplasmin inhibition within an intact fibrin clot during the course of clot lysis. J. Biol. Chem. 2004, 279, 13333-13339. [CrossRef] [PubMed]

76. Miljić, P.; Heylen, E.; Willemse, J.; Djordjevic, V.; Radojkovic, D.; Colovic, M.; Elezovic, I.; Hendriks, D. Thrombin activatable fibrinolysis inhibitor (TAFI): A molecular link between coagulation and fibrinolysis. Srp. Arh. Celok. Lek. 2010, 138 (Suppl. S1), 74-78. [CrossRef] [PubMed]

77. Boffa, M.; Wang, W.; Bajzar, L.; Nesheim, M.E. Plasma and recombinant thrombin-activable fibrinolysis inhibitor (TAFI) and activated TAFI compared with respect to glycosylation, thrombin/thrombomodulin-dependent activation, thermal stability, and enzymatic properties. J. Biol. Chem. 1998, 273, 2127-2135. [CrossRef]

78. Brouwers, G.J.; Vos, H.L.; Leebeek, F.W.; Bulk, S.; Schneider, M.; Boffa, M.; Koschinsky, M.; van Tilburg, N.H.; Nesheim, M.E.; Bertina, R.M.; et al. A novel, possibly functional, single nucleotide polymorphism in the coding region of the thrombin-activatable fibrinolysis inhibitor (TAFI) gene is also associated with TAFI levels. Blood 2001, 98, 1992-1993. [CrossRef]

79. Schneider, M.; Boffa, M.; Stewart, R.; Rahman, M.; Koschinsky, M.; Nesheim, M. Two naturally occurring variants of TAFI (Thr-325 and Ile-325) differ substantially with respect to thermal stability and antifibrinolytic activity of the enzyme. J. Biol. Chem. 2002, 277, 1021-1030. [CrossRef]

80. Franco, R.F.; Fagundes, M.G.; Meijers, J.C.; Reitsma, P.H.; Lourenço, D.; Morelli, V.; Maffei, F.H.; Ferrari, I.C.; Piccinato, C.E.; Silva, W.A.; et al. Identification of polymorphisms in the $5^{\prime}$-untranslated region of the TAFI gene: Relationship with plasma TAFI levels and risk of venous thrombosis. Haematologica 2001, 86, 510-517.

81. Zidane, M.; de Visser, M.C.H.; Wolde, M.T.; Vos, H.L.; de Monyé, W.; Bertina, R.M.; Huisman, M.V.; The Antelope study group. Frequency of the TAFI -438 G/A and factor XIIIA Val34Leu polymorphisms in patients with objectively proven pulmonary embolism. Thromb. Haemost. 2003, 90, 439-445. [CrossRef]

82. Martini, C.; Brandts, A.; de Bruijne, E.; Vlieg, A.V.H.; Leebeek, F.; Lisman, T.; Rosendaal, F. The effect of genetic variants in the thrombin activatable fibrinolysis inhibitor (TAFI) gene on TAFI-antigen levels, clot lysis time and the risk of venous thrombosis. Br. J. Haematol. 2006, 134, 92-94. [CrossRef]

83. Valnickova, Z.; Christensen, T.; Skottrup, P.; Thøgersen, I.B.; Højrup, P.; Enghild, J.J. Post-translational modifications of human thrombin-activatable fibrinolysis inhibitor (TAFI): Evidence for a large shift in the isoelectric point and reduced solubility upon activation. Biochemistry 2006, 45, 1525-1535. [CrossRef]

84. Colucci, M.; Binetti, B.M.; Branca, M.G.; Clerici, C.; Morelli, A.; Semeraro, N.; Gresele, P. Deficiency of thrombin activatable fibrinolysis inhibitor in cirrhosis is associated with increased plasma fibrinolysis. Hepatology 2003, 38, 230-237. [CrossRef]

85. Nagashima, M.; Yin, Z.F.; Zhao, L.; White, K.; Zhu, Y.; Lasky, N.; Halks-Miller, M.; Broze, G.J., Jr.; Fay, W.P.; Morser, J. Thrombinactivatable fibrinolysis inhibitor (TAFI) deficiency is compatible with murine life. J. Clin. Investig. 2002, 109, 101-110. [CrossRef] [PubMed]

86. Mao, S.-S.; Holahan, M.A.; Bailey, C.; Wu, G.; Colussi, D.; Carroll, S.S.; Cook, J.J. Demonstration of enhanced endogenous fibrinolysis in thrombin activatable fibrinolysis inhibitor-deficient mice. Blood Coagul. Fibrinolysis 2005, 16, 407-415. [CrossRef]

87. Wang, X.; Smith, P.L.; Hsu, M.-Y.; Tamasi, J.A.; Bird, E.; Schumacher, W.A. Deficiency in thrombin-activatable fibrinolysis inhibitor (TAFI) protected mice from ferric chloride-induced vena cava thrombosis. J. Thromb. Thrombolysis 2007, 23, 41-49. [CrossRef] [PubMed] 
88. Vercauteren, E.; Peeters, M.; Hoylaerts, M.F.; Lijnen, H.R.; Meijers, J.C.M.; Declerck, P.J.; Gils, A. The hyperfibrinolytic state of mice with combined thrombin-activatable fibrinolysis inhibitor (TAFI) and plasminogen activator inhibitor-1 gene deficiency is critically dependent on TAFI deficiency. J. Thromb. Haemost. 2012, 10, 2555-2562. [CrossRef]

89. Wyseure, T.; Yang, T.; Zhou, J.Y.; Cooke, E.J.; Wanko, B.; Olmer, M.; Agashe, R.; Morodomi, Y.; Behrendt, N.; Lotz, M.; et al. TAFI deficiency causes maladaptive vascular remodeling after hemophilic joint bleeding. JCI Insight 2019, 4, e128379. [CrossRef] [PubMed]

90. Van Tilburg, N.H.; Rosendaal, F.R.; Bertina, R.M. Thrombin activatable fibrinolysis inhibitor and the risk for deep vein thrombosis. Blood 2000, 95, 2855-2859. [CrossRef] [PubMed]

91. Eichinger, S.; Schönauer, V.; Weltermann, A.; Minar, E.; Bialonczyk, C.; Hirschl, M.; Schneider, B.; Quehenberger, P.; Kyrle, P.A. Thrombin-activatable fibrinolysis inhibitor and the risk for recurrent venous thromboembolism. Blood 2004, 103, 3773-3776. [CrossRef] [PubMed]

92. Leebeek, F.W.G.; Goor, M.P.J.; Guimarães, A.H.C.; Brouwers, G.-J.; Maat, M.P.M.; Dippel, D.W.J.; Rijken, D.C. High functional levels of thrombin-activatable fibrinolysis inhibitor are associated with an increased risk of first ischemic stroke. J. Thromb. Haemost. 2005, 3, 2211-2218. [CrossRef] [PubMed]

93. Kamphuisen, P.W.; Ten Wolde, M.; Jacobs, E.M.G.; Ullmann, E.F.; Büller, H.R. Screening of high factor VIII levels is not recommended in patients with recently diagnosed pulmonary embolism. J. Thromb. Haemost. 2003, 1, 2239-2240. [CrossRef]

94. Schielen, W.J.; Voskuilen, M.; Tesser, G.I.; Nieuwenhuizen, W. The sequence A alpha-(148-160) in fibrin, but not in fibrinogen, is accessible to monoclonal antibodies. Proc. Natl. Acad. Sci. USA 1989, 86, 8951-8954. [CrossRef]

95. Janssen, B.; Huizinga, E.G.; Raaijmakers, H.C.A.; Roos, A.; Daha, M.R.; Nilsson-Ekdahl, K.; Nilsson, B.; Gros, P. Structures of complement component C3 provide insights into the function and evolution of immunity. Nature 2005, 437, 505-511. [CrossRef] [PubMed]

96. Whitehead, A.S.; Solomon, E.; Chambers, S.; Bodmer, W.; Povey, S.; Fey, G. Assignment of the structural gene for the third component of human complement to chromosome 19. Proc. Natl. Acad. Sci. USA 1982, 79, 5021-5025. [CrossRef]

97. Vik, D.P.; Amiguet, P.; Moffat, G.J.; Fey, M.; Amiguet-Barras, F.; Wetsel, R.A.; Tack, B.F. Structural features of the human C3 gene: Intron/exon organization, transcriptional start site, and promoter region sequence. Biochemistry 1991, 30, 1080-1085. [CrossRef] [PubMed]

98. Ricklin, D.; Reis, E.S.; Mastellos, D.C.; Gros, P.; Lambris, J.D. Complement component C3—The "Swiss Army Knife" of innate immunity and host defense. Immunol. Rev. 2016, 274, 33-58. [CrossRef]

99. Morgan, B.P.; Gasque, P. Extrahepatic complement biosynthesis: Where, when and why? Clin. Exp. Immunol. 1997, 107, 1-7. [CrossRef]

100. Amara, U.; Flierl, M.A.; Rittirsch, D.; Klos, A.; Chen, H.; Acker, B.; Brückner, U.B.; Nilsson, B.; Gebhard, F.; Lambris, J.D.; et al. Molecular intercommunication between the complement and coagulation systems. J. Immunol. 2010, 185, 5628-5636. [CrossRef]

101. Distelmaier, K.; Adlbrecht, C.; Jakowitsch, J.; Winkler, S.; Dunkler, D.; Gerner, C.; Wagner, O.; Lang, I.M.; Kubicek, M. Local complement activation triggers neutrophil recruitment to the site of thrombus formation in acute myocardial infarction. Thromb. Haemost. 2009, 102, 564-572. [CrossRef] [PubMed]

102. Howes, J.M.; Richardson, V.R.; Smith, K.A.; Schroeder, V.; Somani, R.; Shore, A.; Hess, K.; Ajjan, R.; Pease, R.J.; Keen, J.N.; et al. Complement C3 is a novel plasma clot component with anti-fibrinolytic properties. Diabetes Vasc. Dis. Res. 2012, 9, $216-225$. [CrossRef] [PubMed]

103. King, R.J.; Schuett, K.; Tiede, C.; Jankowski, V.; John, V.; Trehan, A.; Simmons, K.; Ponnambalam, S.; Storey, R.F.; Fishwick, C.W.G.; et al. Fibrinogen interaction with complement C3: A potential therapeutic target to reduce thrombosis risk. Haematologica 2021, 106, 1616-1623. [CrossRef] [PubMed]

104. Richardson, V.R.; Schroeder, V.; Grant, P.J.; Standeven, K.F.; Carter, A.M. Complement C3 is a substrate for activated factor XIII that is cross-linked to fibrin during clot formation. Br. J. Haematol. 2013, 160, 116-119. [CrossRef]

105. Nikolajsen, C.L.; Scavenius, C.; Enghild, J.J. Human complement C3 is a substrate for transglutaminases. A functional link between non-protease-based members of the coagulation and complement cascades. Biochemistry 2012, 51, 4735-4742. [CrossRef]

106. Ajjan, R.; Futers, T.S.; Brown, J.M.; Cymbalista, C.M.; Boothby, M.; Carter, A.M.; Grant, P.J. Complement C3 and C-reactive protein levels in patients with stable coronary artery disease. Thromb. Haemost. 2005, 94, 1048-1053. [CrossRef]

107. Onat, A.; Uzunlar, B.; Hergenç, G.; Yazici, M.; Sari, I.; Uyarel, H.; Can, G.; Sansoy, V. Cross-sectional study of complement C3 as a coronary risk factor among men and women. Clin. Sci. 2005, 108, 129-135. [CrossRef]

108. Széplaki, G.; Prohaszka, Z.; Duba, J.; Rugonfalvi-Kiss, S.; Karádi, I.; Kókai, M.; Kramer, J.; Füst, G.; Kleiber, M.; Romics, L.; et al. Association of high serum concentration of the third component of complement (C3) with pre-existing severe coronary artery disease and new vascular events in women. Atherosclerosis 2004, 177, 383-389. [CrossRef]

109. Carter, A.M.; Prasad, U.K.; Grant, P.J. Complement C3 and C-reactive protein in male survivors of myocardial infarction. Atherosclerosis 2009, 203, 538-543. [CrossRef]

110. Hess, K.; Alzahrani, S.H.; Mathai, M.; Schroeder, V.; Carter, A.M.; Howell, G.J.; Koko, T.; Strachan, M.W.J.; Price, J.; Smith, K.; et al. A novel mechanism for hypofibrinolysis in diabetes: The role of complement C3. Diabetologia 2012, 55, 1103-1113. [CrossRef]

111. Hess, K.; Alzahrani, S.H.; Price, J.F.; Strachan, M.W.; Oxley, N.; King, R.; Gamlen, T.; Schroeder, V.; Baxter, P.D.; Ajjan, R.A. Hypofibrinolysis in type 2 diabetes: The role of the inflammatory pathway and complement C3. Diabetologia 2014, 57, 1737-1741. [CrossRef] 
112. Lokki, A.I.; Kaartokallio, T.; Holmberg, V.; Onkamo, P.; Koskinen, L.L.E.; Saavalainen, P.; Heinonen, S.; Kajantie, E.; Kere, J.; Kivinen, K.; et al. Analysis of Complement C3 Gene Reveals Susceptibility to Severe Preeclampsia. Front. Immunol. 2017, 8, 589. [CrossRef]

113. Zhang, J.; Li, S.; Hu, S.; Yu, J.; Xiang, Y. Association between genetic variation of complement C3 and the susceptibility to advanced age-related macular degeneration: A meta-analysis. BMC Ophthalmol. 2018, 18, 274. [CrossRef]

114. Yates, J.R.; Sepp, T.; Matharu, B.K.; Khan, J.C.; Thurlby, D.A.; Shahid, H.; Clayton, D.G.; Hayward, C.; Morgan, J.; Wright, A.F.; et al. Complement C3 variant and the risk of age-related macular degeneration. N. Engl. J. Med. 2007, 357, 553-561. [CrossRef]

115. Sandhu, V.; Quan, M. SLE and Serum Complement: Causative, Concomitant or Coincidental? Open Rheumatol. J. 2017, 11, 113-122. [CrossRef] [PubMed]

116. Ajjan, R.A.; Grant, P.J.; Futers, T.S.; Brown, J.M.; Carter, A.M. The association of complement C3 genotype with coronary artery disease, markers of the metabolic syndrome and C3 plasma levels. Thromb. Haemost. 2006, 95, 393-394. [CrossRef]

117. Hair, P.S.; Echague, C.G.; Rohn, R.D.; Krishna, N.K.; Nyalwidhe, J.O.; Cunnion, K.M. Hyperglycemic conditions inhibit C3mediated immunologic control of Staphylococcus aureus. J. Transl. Med. 2012, 10, 35. [CrossRef]

118. Ghannam, A.; Pernollet, M.; Fauquert, J.-L.; Monnier, N.; Ponard, D.; Villiers, M.-B.; Péguet-Navarro, J.; Tridon, A.; Lunardi, J.; Gerlier, D.; et al. Human C3 deficiency associated with impairments in dendritic cell differentiation, memory B cells, and regulatory T cells. J. Immunol. 2008, 181, 5158-5166. [CrossRef]

119. Gotz, P.; Braumandl, A.; Kübler, M.; Kumaraswami, K.; Ishikawa-Ankerhold, H.; Lasch, M.; Deindl, E. C3 Deficiency Leads to Increased Angiogenesis and Elevated Pro-Angiogenic Leukocyte Recruitment in Ischemic Muscle Tissue. Int. J. Mol. Sci. 2021, 22, 5800. [CrossRef] [PubMed]

120. Wu, X.; Lin, L.; Cui, J.; Chen, Y.; Yang, L.; Wan, J. Complement C3 deficiency ameliorates aging related changes in the kidney. Life Sci. 2020, 260, 118370. [CrossRef] [PubMed]

121. Dahm, A.E.A.; Jacobsen, E.M.; Wik, H.S.; Jacobsen, A.F.; Mollnes, T.E.; Kanse, S.M.; Sandset, P.M. Elevated Complement C3 and C4 Levels are Associated with Postnatal Pregnancy-Related Venous Thrombosis. Thromb. Haemost. 2019, 119, 1481-1488. [CrossRef] [PubMed]

122. Petri, M.A.; Conklin, J.; O’Malley, T.; Dervieux, T. Platelet-bound C4d, low C3 and lupus anticoagulant associate with thrombosis in SLE. Lupus Sci. Med. 2019, 6, e000318. [CrossRef] [PubMed]

123. Ekdahl, K.N.; Rönnblom, L.; Nilsson, B.; Sturfelt, G. Increased phosphate content in complement component C3, fibrinogen, vitronectin, and other plasma proteins in systemic lupus erythematosus: Covariation with platelet activation and possible association with thrombosis. Arthritis Rheum. 1997, 40, 2178-2186. [CrossRef] [PubMed]

124. Genton, C.; Kruithof, E.K.; Schleuning, W.D. Phorbol ester induces the biosynthesis of glycosylated and nonglycosylated plasminogen activator inhibitor 2 in high excess over urokinase-type plasminogen activator in human U-937 lymphoma cells. J. Cell Biol. 1987, 104, 705-712. [CrossRef]

125. Medcalf, R.L.; Stasinopoulos, S.J. The undecided serpin. The ins and outs of plasminogen activator inhibitor type 2. FEBS J. 2005, 272, 4858-4867. [CrossRef]

126. Kruithof, E.K.; Baker, M.S.; Bunn, C.L. Biological and clinical aspects of plasminogen activator inhibitor type 2. Blood 1995, 86 , 4007-4024. [CrossRef]

127. Ye, R.D.; Ahern, S.M.; Le Beau, M.M.; Lebo, R.V.; Sadler, J.E. Structure of the gene for human plasminogen activator inhibitor-2. The nearest mammalian homologue of chicken ovalbumin. J. Biol. Chem. 1989, 264, 5495-5502. [CrossRef]

128. Kawano, T.; Morimoto, K.; Uemura, Y. Urokinase inhibitor in human placenta. Nature 1968, 217, 253-254. [CrossRef]

129. Wun, T.C.; Reich, E. An inhibitor of plasminogen activation from human placenta. Purification and characterization. J. Biol. Chem. 1987, 262, 3646-3653.

130. Kruithof, E.K.; Tran-Thang, C.; Gudinchet, A.; Hauert, J.; Nicoloso, G.; Genton, C.; Welti, H.; Bachmann, F. Fibrinolysis in pregnancy: A study of plasminogen activator inhibitors. Blood 1987, 69, 460-466. [CrossRef]

131. Robbie, L.A.; Dummer, S.; Booth, N.A.; Adey, G.D.; Bennett, B. Plasminogen activator inhibitor 2 and urokinase-type plasminogen activator in plasma and leucocytes in patients with severe sepsis. Br. J. Haematol. 2000, 109, 342-348. [CrossRef]

132. Scherrer, A.; Kruithof, E.K.; Grob, J.P. Plasminogen activator inhibitor-2 in patients with monocytic leukemia. Leukemia 1991, 5, 479-486.

133. Jensen, P.H.; Schüler, E.; Woodrow, G.; Richardson, M.; Goss, N.; Højrup, P.; Petersen, T.; Rasmussen, L. A unique interhelical insertion in plasminogen activator inhibitor-2 contains three glutamines, Gln83, Gln84, Gln86, essential for transglutaminasemediated cross-linking. J. Biol. Chem. 1994, 269, 15394-15398. [CrossRef]

134. Jensen, P.H.; Lorand, L.; Ebbesen, P.; Gliemann, J. Type-2 plasminogen-activator inhibitor is a substrate for trophoblast transglutaminase and factor XIIIa. Transglutaminase-catalyzed cross-linking to cellular and extracellular structures. Eur. J. Biochem. 1993, 214, 141-146. [CrossRef] [PubMed]

135. Robbie, L.A.; Kinghorn, S.; Exley, R.; Booth, N.A.; Ritchie, H. Monocyte plasminogen activator inhibitor 2 (PAI-2) inhibits u-PA-mediated fibrin clot lysis and is cross-linked to fibrin. Thromb. Haemost. 1999, 81, 96-103. [CrossRef]

136. Ritchie, H.; Lawrie, L.C.; Mosesson, M.W.; Booth, N.A. Characterization of crosslinking sites in fibrinogen for plasminogen activator inhibitor 2 (PAI-2). Ann. N. Y. Acad. Sci. USA 2001, 936, 215-218. [CrossRef]

137. Nieuwenhuizen, W. Sites in fibrin involved in the acceleration of plasminogen activation by t-PA. Possible role of fibrin polymerisation. Thromb. Res. 1994, 75, 343-347. [CrossRef] 
138. Ritchie, H.; Lawrie, L.C.; Crombie, P.W.; Mosesson, M.W.; Booth, N.A. Cross-linking of plasminogen activator inhibitor 2 and alpha 2-antiplasmin to fibrin(ogen). J. Biol. Chem. 2000, 275, 24915-24920. [CrossRef]

139. Foy, C.A.; Grant, P.J. PCR-RFLP detection of PAI-2 gene variants: Prevalence in ethnic groups and disease relationship in patients undergoing coronary angiography. Thromb. Haemost. 1997, 77, 955-958. [CrossRef]

140. Buyru, N.; Altinisik, J.; Gurel, C.B.; Ulutin, T. PCR-RFLP detection of PAI-2 variants in myocardial infarction. Clin. Appl. Thromb. Hemost. 2003, 9, 333-336. [CrossRef]

141. Li, X.; Luo, J.-Y.; Zhang, L.; Yang, Y.-N.; Xie, X.; Liu, F.; Chen, B.-D.; Ma, Y.-T. Variant of PAI-2 gene is associated with coronary artery disease and recurrent coronary event risk in Chinese Han population. Lipids Health Dis. 2015, 14, 148. [CrossRef]

142. Saffari, B.; Jooyan, N.; Bahari, M.; Senemar, S.; Yavarian, M. Lack of association between Ser(413)/Cys polymorphism of plasminogen activator inhibitor type 2 (PAI-2) and premature coronary atherosclerotic disease. EXCLI J. 2012, 11, 407-415. [PubMed]

143. Dougherty, K.M.; Pearson, J.M.; Yang, A.Y.; Westrick, R.J.; Baker, M.S.; Ginsburg, D. The plasminogen activator inhibitor-2 gene is not required for normal murine development or survival. Proc. Natl. Acad. Sci. USA 1999, 96, 686-691. [CrossRef]

144. Westrick, R.J.; Røjkjær, L.P.; Yang, A.Y.; Roh, M.H.; Siebert, A.E.; Ginsburg, D. Deficiency of plasminogen activator inhibitor-2 results in accelerated tumor growth. J. Thromb. Haemost. 2020, 18, 2968-2975. [CrossRef] [PubMed]

145. Siefert, S.A.; Chabasse, C.; Mukhopadhyay, S.; Hoofnagle, M.; Strickland, D.K.; Sarkar, R.; Antalis, T.M. Enhanced venous thrombus resolution in plasminogen activator inhibitor type-2 deficient mice. J. Thromb. Haemost. 2014, 12, 1706-1716. [CrossRef]

146. Reed, G.L., 3rd; Matsueda, G.R.; Haber, E. Inhibition of clot-bound alpha 2-antiplasmin enhances in vivo thrombolysis. Circulation 1990, 82, 164-168. [CrossRef] [PubMed]

147. Reed, G.L., 3rd; Matsueda, G.R.; Haber, E. Synergistic fibrinolysis: Combined effects of plasminogen activators and an antibody that inhibits alpha 2-antiplasmin. Proc. Natl. Acad. Sci. USA 1990, 87, 1114-1118. [CrossRef]

148. Reed, G.L., 3rd; Matsueda, G.R.; Haber, E. Acceleration of plasma clot lysis by an antibody to alpha 2-antiplasmin. Trans. Assoc. Am. Physicians 1988, 101, 250-256. [PubMed]

149. Sakata, Y.; Eguchi, Y.; Mimuro, J.; Matsuda, M.; Sumi, Y. Clot lysis induced by a monoclonal antibody against alpha 2-plasmin inhibitor. Blood 1989, 74, 2692-2697. [CrossRef]

150. Houng, A.K.; Wang, D.; Reed, G.L. Reversing the deleterious effects of alpha2-antiplasmin on tissue plasminogen activator therapy improves outcomes in experimental ischemic stroke. Exp. Neurol. 2014, 255, 56-62. [CrossRef]

151. Singh, S.; Houng, A.; Reed, G.L. Releasing the Brakes on the Fibrinolytic System in Pulmonary Emboli: Unique Effects of Plasminogen Activation and $\alpha 2$-Antiplasmin Inactivation. Circulation 2017, 135, 1011-1020. [CrossRef]

152. Ichinose, A.; Tamaki, T.; Aoki, N. Factor XIII-mediated cross-linking of NH2-terminal peptide of alpha 2-plasmin inhibitor to fibrin. FEBS Lett. 1983, 153, 369-371. [CrossRef]

153. Kimura, S.; Tamaki, T.; Aoki, N. Acceleration of fibrinolysis by the N-terminal peptide of alpha 2-plasmin inhibitor. Blood 1985, 66, 157-160. [CrossRef] [PubMed]

154. Sheffield, W.P.; Eltringham-Smith, L.J.; Gataiance, S.; Bhakta, V. Addition of a sequence from alpha2-antiplasmin transforms human serum albumin into a blood clot component that speeds clot lysis. BMC Biotechnol. 2009, 9, 15. [CrossRef] [PubMed]

155. Pakola, S.; Cahillane, G.; Stassen, J.-M.; Lijnen, H.R.; Verhamme, P. Neutralization of alpha(2)-antiplasmin by microplasmin: A randomized, double-blind, placebo-controlled, ascending-dose study in healthy male volunteers. Clin. Ther. 2009, 31, 1688-1706. [CrossRef]

156. Sansilvestri-Morel, P.; Rupin, A.; Schaffner, A.-P.; Bertin, F.; Mennecier, P.; Lapret, I.; Declerck, P.J.; Baumy, P.; Vallez, M.-O.; Petit-Dop, F.; et al. S62798, a potent TAFIa inhibitor, accelerates endogenous fibrinolysis in a murine model of pulmonary thromboembolism. Thromb. Res. 2021, 204, 81-87. [CrossRef]

157. Klement, P.; Liao, P.; Bajzar, L. A novel approach to arterial thrombolysis. Blood 1999, 94, 2735-2743. [CrossRef]

158. da Cunha, V.; Vincelette, J.; Zhao, L.; Nagashima, M.; Kawai, K.; Yuan, S.; Emayan, K.; Islam, I.; Hosoya, J.; Sullivan, M.E.; et al. A novel inhibitor of activated thrombin activatable fibrinolysis inhibitor (TAFIa)—Part II: Enhancement of both exogenous and endogenous fibrinolysis in animal models of thrombosis. Thromb. Haemost. 2007, 97, 54-61. [CrossRef]

159. Noguchi, K.; Edo, N.; Miyoshi, N.; Isobe, A.; Watanabe, A.; Ito, Y.; Morishima, Y.; Yamaguchi, K. Fibrinolytic potential of DS-1040, a novel orally available inhibitor of activated thrombin-activatable fibrinolysis inhibitor (TAFIa). Thromb. Res. 2018, 168, 96-101. [CrossRef]

160. Zhou, J.; Limsakun, T.; Yin, O.; Warren, V.; Zamora, C.; Atiee, G.; Kochan, J.; Pav, J.; Kobayashi, F.; Vashi, V.; et al. First-in-Human Study to Assess the Safety, Pharmacokinetics, and Pharmacodynamics of an Oral Formulation of DS-1040, an Inhibitor of the Activated Form of Thrombin-Activatable Fibrinolysis Inhibitor, in Healthy Subjects. J. Clin. Pharmacol. 2019, 59, 1669-1677. [CrossRef] [PubMed]

161. Gils, A.; Ceresa, E.; Macovei, A.M.; Marx, P.F.; Peeters, M.; Compernolle, G.; Declerck, P.J. Modulation of TAFI function through different pathways-implications for the development of TAFI inhibitors. J. Thromb. Haemost. 2005, 3, 2745-2753. [CrossRef] [PubMed]

162. Hillmayer, K.; Vancraenenbroeck, R.; DE Maeyer, M.; Compernolle, G.; Declerck, P.J.; Gils, A. Discovery of novel mechanisms and molecular targets for the inhibition of activated thrombin activatable fibrinolysis inhibitor. J. Thromb. Haemost. 2008, 6, 1892-1899. [CrossRef] 
163. Vercauteren, E.; Emmerechts, J.; Peeters, M.; Hoylaerts, M.F.; Declerck, P.J.; Gils, A. Evaluation of the profibrinolytic properties of an anti-TAFI monoclonal antibody in a mouse thromboembolism model. Blood 2011, 117, 4615-4622. [CrossRef]

164. Hendrickx, M.L.; Zatloukalova, M.; Hassanzadeh-Ghassabeh, G.; Muyldermans, S.; Gils, A.; Declerck, P.J. Identification of a novel, nanobody-induced, mechanism of TAFI inactivation and its in vivo application. J. Thromb. Haemost. 2014, 12, 229-236. [CrossRef] [PubMed]

165. Wyseure, T.; Rubio, M.; Denorme, F.; De Lizarrondo, S.M.; Peeters, M.; Gils, A.; De Meyer, S.; Vivien, D.; Declerck, P.J. Innovative thrombolytic strategy using a heterodimer diabody against TAFI and PAI-1 in mouse models of thrombosis and stroke. Blood 2015, 125, 1325-1332. [CrossRef] [PubMed]

166. King, R.; Tiede, C.; Simmons, K.; Fishwick, C.; Tomlinson, D.; Ajjan, R. Inhibition of complement C3 and fibrinogen interaction: A potential novel therapeutic target to reduce cardiovascular disease in diabetes. Lancet 2015, 385 (Suppl. S1), S57. [CrossRef]

167. Mastellos, D.C.; Pires da Silva, B.G.P.; Fonseca, B.A.L.; Fonseca, N.P.; Auxiliadora-Martins, M.; Mastaglio, S.; Ruggeri, A.; Sironi, M.; Radermacher, P.; Chrysanthopoulou, A.; et al. Complement C3 vs C5 inhibition in severe COVID-19: Early clinical findings reveal differential biological efficacy. Clin. Immunol. 2020, 220, 108598. [CrossRef]

168. Risitano, A.M.; Mastellos, D.C.; Huber-Lang, M.; Yancopoulou, D.; Garlanda, C.; Ciceri, F.; Lambris, J.D. Complement as a target in COVID-19? Nat. Rev. Immunol. 2020, 20, 343-344. [CrossRef]

169. Mastellos, D.C.; Ricklin, D.; Lambris, J.D. Clinical promise of next-generation complement therapeutics. Nat. Rev. Drug Discov. 2019, 18, 707-729. [CrossRef]

170. de Castro, C.; Grossi, F.; Weitz, I.C.; Maciejewski, J.; Sharma, V.; Roman, E.; Brodsky, R.A.; Tan, L.; Di Casoli, C.; El Mehdi, D.; et al. C3 inhibition with pegcetacoplan in subjects with paroxysmal nocturnal hemoglobinuria treated with eculizumab. Am. J. Hematol. 2020, 95, 1334-1343. [CrossRef]

171. Peacock-Young, B.; Macrae, F.L.; Newton, D.J.; Hill, A.; Ariëns, R.A. The prothrombotic state in paroxysmal nocturnal hemoglobinuria: A multifaceted source. Haematologica 2018, 103, 9-17. [CrossRef] [PubMed]

172. Weyand, A.C.; Pipe, S.W. New therapies for hemophilia. Blood 2019, 133, 389-398. [CrossRef]

173. Mosnier, L.O.; Lisman, T.; Berg, M.V.D.H.; Nieuwenhuis, K.H.; Meijers, J.C.; Bouma, B.N. The defective down regulation of fibrinolysis in haemophilia A can be restored by increasing the TAFI plasma concentration. Thromb. Haemost. 2001, 86, 1035-1039. [CrossRef] [PubMed]

174. Foley, J.; Petersen, K.-U.; Rea, C.J.; Harpell, L.; Powell, S.; Lillicrap, D.; Nesheim, M.E.; Sørensen, B. Solulin increases clot stability in whole blood from humans and dogs with hemophilia. Blood 2012, 119, 3622-3628. [CrossRef]

175. Chan, L.W.; Kim, C.H.; Wang, X.; Pun, S.H.; White, N.J.; Kim, T.H. PolySTAT-modified chitosan gauzes for improved hemostasis in external hemorrhage. Acta Biomater. 2016, 31, 178-185. [CrossRef]

176. Kearney, K.; Pechlivani, N.; King, R.; Tiede, C.; Phoenix, F.; Cheah, R.; Macrae, F.; Simmons, K.; Manfield, I.W.; Smith, K.A.; et al. Affimer proteins as a tool to modulate fibrinolysis, stabilize the blood clot, and reduce bleeding complications. Blood 2019, 133, 1233-1244. [CrossRef] [PubMed] 